\section{Thrombin Stimulates Tissue Plasminogen Activator Release from Cultured Human Endothelial Cells}

\author{
Eugene G. Levin, Ulla Marzec, Johanna Anderson, \\ and Laurence A. Harker \\ Roon Research Center for Arteriosclerosis and Thrombosis, \\ Department of Basic and Clinical Research, Scripps Clinic and \\ Research Foundation, La Jolla, California 92037
}

A of tissue plasminogen activator from endothelial cells was studied in primary cultures of human umbilical vein endothelial cells. Tissue plasminogen activator concentration in conditioned medium was measured by a two-site radioimmunometric assay. The addition of increasing concentrations $(0.01$ to $10 \mathrm{U} / \mathrm{ml})$ of thrombin to confluent cultures produced a saturable, dose-dependent increase in the rate of release of tissue plasminogen activator. A sixfold increase in tissue plasminogen activator concentration (from 2 to $12 \mathrm{ng} / \mathrm{ml}$ ) occurred after the addition of $1 \mathrm{U} / \mathrm{ml}$ thrombin $\left(8 \times 10^{-9} \mathrm{M}\right)$ to cultures containing $5 \times 10^{4}$ cells $/ \mathrm{cm}^{2}$. Enhanced release was not observed until $6 \mathrm{~h}$ after thrombin addition, reached a maximum rate of $1.3 \mathrm{ng} / \mathrm{ml}$ per $\mathrm{h}$ between 8 and $16 \mathrm{~h}$, and then declined to $0.52 \mathrm{ng} / \mathrm{ml}$ per $\mathrm{h}$ after $16 \mathrm{~h}$. The 6-h lag period before increased tPA release was reproducible and independent of thrombin concentration. Thrombin inactivated with diisopropylfluorophosphate or hirudin did not induce an increase in tissue plasminogen activator levels. A 50-fold excess of diisopropylfluorophosphate-treated thrombin, which inhibits binding of active thrombin to endothelial cell high affinity binding sites, did not inhibit the thrombin-induced increase. It is concluded that proteolitically active thrombin causes an increase in the rate of release of

This work was presented in part at the Annual Meeting of the American Society of Hematology, San Francisco, California, 3-6 December 1983, and published in abstract (1983. Blood. 62:287a).

Address reprint request to Dr. Levin, Department of Basic and Clinical Research, Scripps Clinic and Research Foundation, 10666 North Torrey Pines Road, La Jolla, CA 92037.

Received for publication 5 March 1984 and in revised form 19 June 1984.

J. Clin. Invest.

(c) The American Society for Clinical Investigation, Inc. $0021-9738 / 84 / 12 / 1988 / 08 \quad \$ 1.00$

Volume 74, December 1984, 1988-1995 tissue plasminogen activator from cultured human endothelial cells. The 6-h interval between thrombin treatment and enhanced tissue plasminogen activator release may reflect a delaying mechanism that transiently protects hemostatic plugs from the sudden increase in the local concentration of this fibrinolytic enzyme.

\section{Introduction}

Thrombin has been shown to affect the synthesis, release, or activation of a variety of plasma components through its interaction with the vascular endothelium (1-6). Two of these demonstrated effects could play a role in the regulation of the fibrinolytic pathway: the activation of protein $C(5)$, which generates an increase in plasma fibrinolytic activity in vivo (7), and the thrombin-induced decline of intracellular plasminogen activator activity and plasminogen activator release from bovine aortic endothelial cells in culture (4). This latter effect is quite dramatic, as shown by the suppression of plasminogen activator activity occurring within minutes after the addition of thrombin. Studies performed to determine which of the two immunochemically distinct plasminogen activators released by the bovine endothelial cells (urokinase or tissue plasminogen activator [8]) was affected by the addition of thrombin demonstrated a decline in the level of urokinase with no significant effect upon tissue plasminogen activator (tPA) ${ }^{1}$ activity (9).

Primary cultures of human umbilical vein endothelial cells release a single plasminogen activator, which is immunochemically related to tPA (10). Unlike in the supernatant of bovine endothelial cells, no urokinase is detected in the supernatant of cultured human endothelial cells. The tPA has a molecular weight of 100,000 , does not bind to fibrin, and is inactive. It has been suggested that these unusual characteristics result from an association between the IPA and an endothelial cell synthesized inhibitor through a sodium dodecyl sulfate (SDS)stable bond (10). This fibrinolytic inhibitor, found in the culture medium of human endothelial cells, is present in

1. Abbreviations used in this paper: DFP, diisopropylfluorophosphate; DMEM, Dulbecco's modified Eagle's medium; PAGE, polyacrylamide gel electrophoresis; tPA, tissue plasminogen activator. 
excess (10-12). The addition of purified human tPA to the endothelial cell conditioned medium resulted in an increase in the molecular weight of this tPA by 40,000 and a disappearance of tPA activity (10).

Because primary cultures of human endothelial cells do not release urokinase-like plasminogen activators it was of interest to determine whether thrombin would affect plasminogen activator release in human endothelial cells in culture. Using a solid-phase radioimmunometric assay (13) we investigated the effect of thrombin on the release of tPA from primary cultures of human endothelial cells. We show that thrombin induces an increase in the release of tPA in a dose and time dependent manner.

\section{Methods}

Materials. Human alpha-thrombin was a gift from Dr. J. W. Fenton (New York Department of Health, Albany, New York) and had a specific activity of 3,642 U/mg thrombin. Diisopropylfluorophosphate (DFP) treated thrombin was prepared by reacting thrombin with 10 $\mathrm{mM}$ DFP at $\mathrm{pH} 7.2$ for $1 \mathrm{~h}$ at $37^{\circ} \mathrm{C}$.

Human tPA was a gift from Dr. D. Collen (University of Leuven, Belgium). tPA-Sepharose was prepared with $\mathrm{CNBr}$-activated Sepharose 4B (Pharmacia Fine Chemicals, Piscataway, NJ) and $100 \mu \mathrm{g}$ of tPA/ $\mathrm{ml}$ of gel. Antisera against tPA were raised in rabbits as described previously (14). The IgG fractions were isolated by ammonium sulfate precipitation and DEAE-cellulose chromatography (8).

Plasminogen was prepared from human plasma by affinity chromatography on lysine-Sepharose (Pharmacia Fine Chemicals) as described (15). Plasminogen-free bovine fibrinogen and lactoperoxidase were obtained from Calbiochem-Behring Corp. (La Jolla, CA). RPMI1640, penicillin, and streptomycin were obtained from Gibco Laboratories, Gibco Div. (Grand Island, NY), fetal bovine serum from Reheis Co., Inc. (Phoenix, AZ), calf skin gelatin from Eastman Chemical Products, Inc. (Rochester, NY), methionine-free Dulbecco's modified Eagle's medium from Irvine Scientific (Santa Ana, CA), and NuSerum from Collaborative Research Inc. (Waltham, MA). Urokinase was a gift from Abbott Laboratories (North Chicago, IL). L- $\left[{ }^{35} \mathrm{~S}\right]$ methionine $(1,166 \mathrm{Ci} / \mathrm{mmol})$ was purchased from New England Nuclear (Boston, MA), and DFP, hirudin, cycloheximide, and actinomycin D were obtained from Sigma Chemical Co. (St. Louis, MO). Flexible microtiter plates (3911) were purchased from Falcon Labware, Div. of Becton, Dickinson \& Co. (Oxnard, CA).

Cell culture. Endothelial cells were isolated from human umbilical cord veins as previously described (6) and were cultured on six-well tissue culture plates coated with $2 \mathrm{mg} / \mathrm{ml}$ calf skin gelatin. Cells were grown to confluence in RPMI-1640 containing 20\% fetal bovine serum, $100 \mathrm{U} / \mathrm{ml}$ penicillin, and $100 \mu \mathrm{g} / \mathrm{ml}$ streptomycin. Primary cultures were used exclusively in these studies. Cell density at confluence was $\sim 5 \times 10^{4}$ cells $/ \mathrm{cm}^{2}$. Experiments were performed on cultures derived from combining the cells obtained from at least four umbilical cords.

Studies were performed by washing confluent cultures twice with RPMI-1640 and incubating the cultures at $37^{\circ} \mathrm{C}$ in $1 \mathrm{ml}$ RPMI-1640 containing $5 \%$ NuSerum (final serum concentration, 1.25\%) and the indicated concentration of thrombin. The conditioned medium was centrifuged at $15,000 \mathrm{~g}$ to remove cell debris, made $0.01 \%$ with Tween 80 , and frozen at $-70^{\circ} \mathrm{C}$ until used. Experiments that were to be analyzed by fibrin autography were performed in $0.55 \mathrm{ml}$ serum-free
RPMI-1640. To determine the effect of transient exposure of thrombin on endothelial cells, cultures were treated with thrombin for the prescribed time, washed three times with RPMI-1640 containing 5\% NuSerum prewarmed to $37^{\circ} \mathrm{C}$, and then incubated in $1 \mathrm{ml}$ of RPMI1640-5\% NuSerum.

${ }^{[3}$ S $]$ methionine labeling of cultures was performed by washing confluent cultures twice with methionine-free DMEM and adding 1 $\mathrm{ml}$ of the same medium containing $10 \mu \mathrm{Ci} / \mathrm{ml}\left[{ }^{35} \mathrm{~S}\right]$ methionine for 15 min. The amount of radioactivity incorporated into cellular and excreted proteins was determined by trichloracetic acid precipitation of cell extracts and conditioned medium, filtration, and counting of precipitable radioactivity.

Preparation of ${ }^{125}$ I-labeled affinity purified anti-tPA IgG. Affinity purified anti-tPA was prepared by passing $2 \mathrm{ml}$ of the IgG fraction of rabbit antiserum $(6 \mathrm{mg} \mathrm{IgG/ml} \mathrm{in} 0.15 \mathrm{M}$ sodium chloride- $0.01 \mathrm{M}$ phosphate, pH 7.2 [phosphate-buffered saline, PBS]) through a 2-ml Sepharose 4B column containing $\sim 600 \mu \mathrm{g}$ tPA. The column was washed with $0.5 \mathrm{M}$ sodium chloride-0.01 $\mathrm{M}$ sodium phosphate, $\mathrm{pH}$ 7.2, and $\operatorname{lgG}$ was eluted with $0.1 \mathrm{M}$ glycine $\mathrm{HCl}, \mathrm{pH} 3.0$. To each eluate fraction was added $50 \mu \mathrm{l}$ of $1 \mathrm{M}$ sodium phosphate $\mathrm{pH} 7.2$ and a final concentration of $1 \%$ bovine serum albumin. The fractions containing the IgG were pooled and dialyzed against PBS. The antibodies were iodinated by the lactoperoxidase method (16). The radioiodinated antibody was then added to $200 \mu$ l of tPA-Sepharose 4B containing $60 \mu \mathrm{g} \mathrm{tPA}$ and mixed for $2 \mathrm{~h}$ at room temperature. The Sepharose was washed with $0.5 \mathrm{M}$ sodium chloride- $0.01 \mathrm{M}$ sodium phosphate, pH 7.2 to remove unbound material. The igG was eluted from the Sepharose with $0.1 \mathrm{M}$ glycine- $\mathrm{HCl}, \mathrm{pH} \mathrm{3.0,} \mathrm{and} \mathrm{the} \mathrm{eluate}$ was dialyzed against PBS.

Radioimmunometric assay. The assay used was modified from Rijken et al. (13). Rabbit anti-tPA IgG was diluted to a final concentration of $10 \mu \mathrm{g} / \mathrm{ml}$ in $50 \mathrm{mM}$ sodium borate buffer, $\mathrm{pH} 9.0$, and 150 $\mu l$ was incubated overnight at $4^{\circ} \mathrm{C}$ in each well of flexible microtiter plates. The contents of the well were removed and the wells were washed twice with PBS containing $0.05 \%$ Tween 20 and $0.1 \%$ albumin. Samples or tPA standards diluted in RPMI-1640-5\% NuSerum (1.25\% fetal bovine serum) were incubated in the antibody coated wells at a volume of $100 \mu \mathrm{l}$ for $5 \mathrm{~h}$ at room temperature on a tilting table. The samples were removed and the wells were washed twice with PBS$0.05 \%$ Tween $20-0.1 \%$ albumin. Radiolabeled immunopurified antibodies $\left(100 \mu \mathrm{l} ; 0.5-1.7 \times 10^{4} \mathrm{cpm}\right)$ dissolved in PBS-1\% albumin$0.01 \%$ Tween 80 were added and the plates were incubated overnight at $4^{\circ} \mathrm{C}$. The wells were washed twice with PBS-0.05\% Tween $20-0.1 \%$ albumbin, cut from the plate, and counted in a gamma-spectrometer. Standard curves were analyzed by logit transformation and linear regression analysis of logit B (percentage counts bound) vs. In tPA concentration (17). Best fitting lines were determined by computer. Standard curve values in the range of 0.5 to $60 \mathrm{ng} / \mathrm{ml}$ were found to give a linear dose-response curve with a correlation coefficient $>0.95$ and a slope of 0.9. Comparison of these standard curves with standard curves performed in PBS indicated that the serum had little or no effect upon the sensitivity or slope of the curves.

Polyacrylamide gel electrophoresis (PAGE) and fibrin autography. SDS-PAGE was performed with $9 \%$ acrylamide gels according to the method of Weber and Osborn (18). Before electrophoresis, $200 \mu \mathrm{l}$ of the conditioned medium samples was dialyzed against SDS-PAGE running buffer for $6 \mathrm{~h}$, then made $1 \%$ with SDS, and incubated at $37^{\circ} \mathrm{C}$ for $30 \mathrm{~min}$. Molecular weight standards included plasminogen $(90,000)$, human transferrin $(76,000)$, bovine serum albumin $(66,200)$, ovalbumin $(45,000)$, and low molecular weight urokinase $(33,000)$. 
To prepare fibrin agar indicator gels (19), a $2 \%$ solution of agarose in water was boiled, cooled to $47^{\circ} \mathrm{C}$ and mixed with prewarmed PBS containing $140 \mu \mathrm{g} / \mathrm{ml}$ plasminogen and $0.8 \mathrm{U} / \mathrm{ml}$ thrombin. Fibrinogen $(10 \mathrm{mg} / \mathrm{ml})$ in $\mathrm{PBS}\left(37^{\circ} \mathrm{C}\right)$ was added and the mixture was poured onto a glass plate. Final concentrations were $1 \%$ agarose, $37 \mu \mathrm{g} / \mathrm{ml}$ plasminogen, $0.2 \mathrm{U} / \mathrm{ml}$ thrombin, and $2 \mathrm{mg} / \mathrm{ml}$ fibrinogen. The fibrinagar gel was used immediately. After electrophoresis, the SDS gels were soaked in $2.5 \%$ Triton X-100 for $1.5 \mathrm{~h}$ to remove the SDS, patted dry with paper towels, and applied to the surface of the fibrin-agar indicator gel. The indicator gel was allowed to develop at $37^{\circ} \mathrm{C}$ in a moist chamber, and then photographed.

Assay of fibrinolytic activity. tPA activity was assayed on ${ }^{125} \mathrm{I}-$ fibrin-coated multiwell tissue culture dishes ( 24 wells, $16 \mathrm{~mm}$; Costar, Data Packaging, Cambridge, MA). The standard cell-free assay contained, in $1 \mathrm{ml}, 4 \mu \mathrm{g}$ of human plasminogen, $0.1 \%$ gelatin, $0.1 \mathrm{M}$ Tris $\mathrm{HCl}, \mathrm{pH} \mathrm{8.1}$, and tPA. The rate of fibrinolysis was determined by measurement of the amount of radioactivity released from the surface of the dish as a function of time. The results were the average of duplicate samples.

tPA inhibitory activity in conditioned medium was measured by the addition of purified tPA to the medium, incubation of the mixture for $30 \mathrm{~min}$ at $37^{\circ} \mathrm{C}$, and assay for residual tPA on ${ }^{125}$ I-fibrin plates. Plasmin is not inhibited by the tPA inhibitor (unpublished observation). Assays were stopped when untreated tPA controls removed 40-50\% of the total radioactivity in the well.

\section{Results}

The tPA present in the culture medium of human endothelial cells is irreversibly bound to an inhibitor (10). Because of the possibility that the presence of this inhibitor might compromise the validity of the tPA radioimmunometric assay, the ability of the assay to measure inhibitor-bound TPA as accurately as free tPA was tested (Table I). $12 \mathrm{ng} / \mathrm{ml}$ of purified tPA was added to serial solutions of conditioned medium which had been previously depleted of endothelial cell tPA (10), and the extent of inhibition was measured by the ${ }^{125}$ I-fibrin plate assay. Each sample was then assayed for tPA concentration by the radioimmunometric assay and the value was compared with values from control samples containing identical concentrations of tPA in the absence of conditioned medium. Regardless of the fraction of IPA that was inactivated by the inhibitor, the concentration of TPA measured by the assay did not significantly differ from the control samples. The average value determined for all dilutions of conditioned medium was $12.1 \pm 0.77 \mathrm{ng} / \mathrm{ml}$. To determine whether the presence of excess free inhibitor altered the assay, $2.5 \mathrm{ng} / \mathrm{ml}$ tPA was added to serial dilutions of conditioned medium, all of which completely inhibited tPA activity. All values measured under these conditions were similar to those of control samples (Table I). The average value was $2.47 \pm 0.39 \mathrm{ng} / \mathrm{ml}$.

To establish the optimum culture conditions for this study, cells were treated with $1 \mathrm{U} / \mathrm{ml}$ thrombin for $16 \mathrm{~h}$ in the presence of serum-free medium or various concentrations of calf serum. The maximum level of tPA in cultures treated in serum-free medium was $6-7 \mathrm{ng} / \mathrm{ml}$ although values as low as $4 \mathrm{ng} / \mathrm{ml}$ were observed. The addition of as little as $0.01 \%$
Table I. Effect of the Association between Inhibitor and tPA on the tPA Radioimmunoassay

\begin{tabular}{llll}
\hline tPA added & $\begin{array}{l}\text { Conditioned } \\
\text { medium }^{*}\end{array}$ & $\begin{array}{l}\text { Inhibited tPA } \\
\text { activity }\end{array}$ & $\begin{array}{l}\text { tPA } \\
\text { measured* }^{*}\end{array}$ \\
\hline $\mathrm{ng} / \mathrm{ml}$ & dilution & $\%$ & $\mathrm{ng} / \mathrm{ml}$ \\
12 & $1: 2$ & 88.5 & 11.5 \\
& $1: 4$ & 71.4 & 12.8 \\
& $1: 8$ & 33.2 & 11.9 \\
2.5 & $1: 2$ & 100 & 2.5 \\
& $1: 4$ & 100 & 2.7 \\
& $1: 8$ & 100 & 2.9 \\
\hline
\end{tabular}

\begin{abstract}
* 24-h endothelial cell conditioned medium was passed through a lysine-Sepharose column to remove tPA and then twofold serial dilutions were performed with RPMI-1640 with a final concentration of $5 \%$ NuSerum. The indicated concentration of purified melanoma cell tPA was added to each sample and the mixture was incubated for 30 min at $37^{\circ} \mathrm{C}$ to allow tPA-inhibitor complex formation. The melanoma cell tPA-conditioned medium samples were assayed for tPA activity by the ${ }^{125}$ I-fibrin plate assay as described in Methods. Control samples consisted of tPA diluted into RPMI-1640-5\% NuSerum only. Values are presented as a percentage of control samples.

* Samples were analyzed for tPA concentration by radioimmunometric assay. Each sample was run in triplicate and the values were averaged.
\end{abstract}

serum resulted in higher levels of tPA, whereas maximum tPA concentrations appeared between $0.1 \%$ and $1.25 \%$ serum (Fig. 1). A rapid decline in tPA concentration occurred in the presence of serum at concentrations $>1.25 \%$. Therefore, to maintain cell viability over prolonged incubation times (up to $48 \mathrm{~h}$ ) without interfering with the efficacy of thrombin in inducing release of tPA, all experiments were performed in $1.25 \%$ serum.

The addition of increasing concentrations of thrombin $(0.001$ to $10 \mathrm{U} / \mathrm{ml})$ to confluent cultures of human endothelial cells for $16 \mathrm{~h}$ resulted in a dose-dependent increase in the level

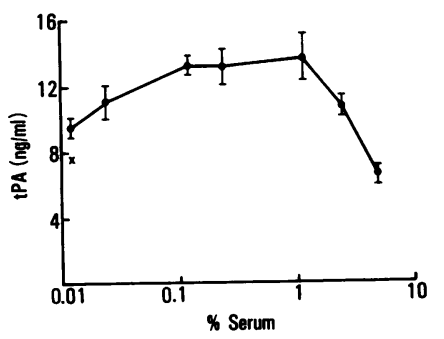

Figure 1. Effect of increasing concentrations of serum on thrombin-induced tPA release. Increasing concentrations of calf serum in RPMI-1640 containing $1 \mathrm{U} / \mathrm{ml}$ thrombin were added to confluent cultures for $16 \mathrm{~h}$. Culture medium was removed, made $0.01 \%$ with Tween 80 , centrifuged at $15,000 \mathrm{~g}$ and analyzed for tPA by radioimmunometric assay. Values determined for TPA in 2.5 and $5 \%$ serum were obtained from a standard curve employing $5 \%$ serum as a diluent. $X$, concentration of tPA in serum-free medium. Each value represents the average of four experiments. 
of tPA in the conditioned medium (Fig. 2). This increase was first detectable with $0.1 \mathrm{U} / \mathrm{ml}$ thrombin $(27 \mathrm{ng} / \mathrm{ml})$. Maximum levels of tPA (12 ng/ml, a sixfold increase) were observed with $1 \mathrm{U} / \mathrm{ml}$ thrombin; thrombin at levels $>1 \mathrm{U} / \mathrm{ml}$ did not induce additional increases in tPA levels.

Changes in the level of tPA were measured at various times during the $24 \mathrm{~h}$ after the addition of $1 \mathrm{U} / \mathrm{ml}$ thrombin (Fig. 3). The release of tPA during the first $6 \mathrm{~h}$ was only slightly increased over control values. However, between 6 and $8 \mathrm{~h}$ the average rate of release rose to $0.64 \mathrm{ng} / \mathrm{ml}$ per $\mathrm{h}$, increased to $1.3 \mathrm{ng} / \mathrm{ml}$ per $\mathrm{h}$ between 8 and $16 \mathrm{~h}$, and then declined to $0.52 \mathrm{ng} / \mathrm{ml}$ per $\mathrm{h}$ from 16 to $24 \mathrm{~h}$. The duration of the initial delay was independent of the concentration of thrombin since cultures treated with $0.1,1$, or $10 \mathrm{U} / \mathrm{ml}$ demonstrated the same lag period. Thus it appears that stimulation of tPA release by thrombin evolves slowly and is delayed $\sim 6 \mathrm{~h}$. When cells were treated with a second dose of $1 \mathrm{U} / \mathrm{ml}$ thrombin at $24 \mathrm{~h}$, either by removal of the original culture medium and addition of fresh medium containing thrombin or by addition of the additional thrombin directly to the existing medium, no secondary enhancement in the rate of tPA release was observed. The increase in tPA concentration between 24 and $48 \mathrm{~h}$ in cultures treated with a second dose of thrombin was similar to that in cultures remaining on the original thrombin (not shown).

Experiments were also performed to determine whether enhanced tPA release depended upon the continued presence of thrombin or whether brief exposure was enough to stimulate tPA release. In these studies cultures were treated for $1 \mathrm{~h}$ with $1 \mathrm{U} / \mathrm{ml}$ thrombin, washed, and incubated for an additional 24 $h$ in thrombin-free medium. The tPA concentration in the 24 $h$ conditioned medium was $3.6 \pm 0.44 \mathrm{ng} / \mathrm{ml}$ as compared with $1.9 \pm 0.58 \mathrm{ng} / \mathrm{ml}$ in untreated cultures. Maximum release of tPA in cultures continuously exposed to thrombin was $13.3 \pm 3.1$

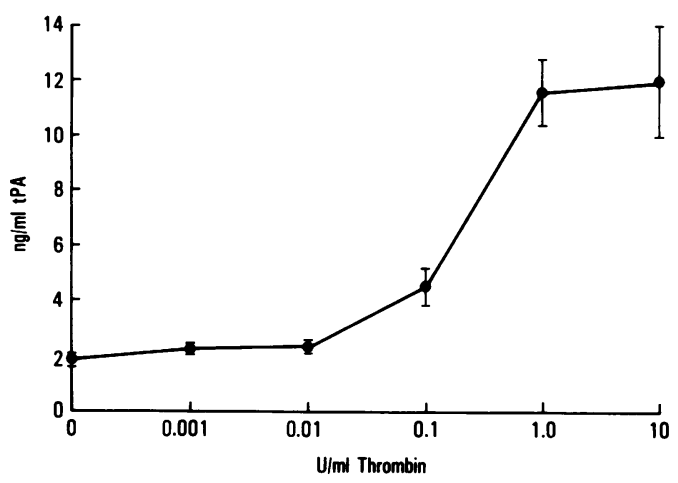

Figure 2. Thrombin-mediated increase of tPA release. Increasing concentrations of thrombin were added to confluent monolayers of endothelial cells and the cultures were incubated for $16 \mathrm{~h}$. The culture medium was removed and made $0.01 \%$ with Tween 80 and centrifuged at $15,000 \mathrm{~g}$, and the TPA was measured by radioimmunometric assay. Each value represents the average of three experiments involving three separate batches of cells.

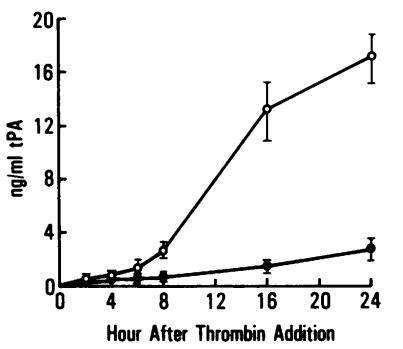

Figure 3. Time course of thrombin-induced tPA release. Confluent cultures of endothelial cells were incubated with or without 1 $\mathrm{U} / \mathrm{ml}$ thrombin for the indicated period. The culture medium was removed, centrifuged, and analyzed for tPA by radioimmunometric assay. Each value represents the average of three experiments involving three separate batches of cells. $0,1 \mathrm{U} / \mathrm{ml}$ thrombin; •, untreated cells.

$\mathrm{ng} / \mathrm{ml}$. When thrombin was allowed to remain on the cultures for 2 or $6 \mathrm{~h}$, the tPA accumulation after $24 \mathrm{~h}$ reached $5.4 \pm 0.58$ and $6.7 \pm 0.72 \mathrm{ng} / \mathrm{ml}$, respectively, i.e., 2.7 and 3.4 times the amount observed in controls. Since little tPA can be detected in the culture medium in the first $6 \mathrm{~h}$ of thrombin treatment the increase must be due to release after thrombin removal. Thus the effect of thrombin, while reversible, did not disappear after the removal of thrombin.

To determine whether the thrombin-stimulated release was specific for tPA or whether thrombin enhanced the release of most proteins in a similar fashion, endothelial cells were treated with $1 \mathrm{U} / \mathrm{ml}$ thrombin for $4,8,16$, and $24 \mathrm{~h}$, and labeled with $\left.{ }^{35} \mathrm{~S}\right]$ methionine for $15 \mathrm{~min}$, and the amount of radiolabeled proteins released into the culture medium was measured (Table II). Comparison of the protein-associated ${ }^{35} \mathrm{~S}$ counts per minute released during the 15 -min period at each time point indicated only a small change in the release of total protein in either thrombin treated or untreated cultures for the entire $24 \mathrm{~h}$. This minor fluctuation in the rate of total protein release after thrombin addition suggests that changes in the rate of tPA release is not a nonspecific event.

Enhanced release of tPA was thrombin active site-dependent since the addition of DFP-treated thrombin $(1 \mathrm{U} / \mathrm{ml})$ did not

Table II. Effect of Thrombin on Total Protein Synthesis and Release*

\begin{tabular}{rlllll}
\hline & \multicolumn{2}{l}{ Cell-associated protein } & & \multicolumn{2}{l}{ Extracellular protein } \\
Hour & + Thrombin & - Thrombin & & + Thrombin & - Thrombin \\
\hline 4 & 297,455 & 234,640 & & 9,588 & 9,897 \\
8 & 338,808 & 211,133 & & 7,877 & 9,916 \\
16 & - & - & & 8,338 & 9,853 \\
24 & 314,375 & 208,076 & & 7,756 & 9,323 \\
\hline
\end{tabular}

* Confluent cultures were incubated in the presence or absence of 1 $\mathrm{U} / \mathrm{ml}$ thrombin for the specified amount of time, washed twice with methionine-free DMEM, and treated with the methionine-free medium containing $10 \mu \mathrm{Ci} / \mathrm{ml}\left[{ }^{35} \mathrm{~S}\right]$ methionine for $15 \mathrm{~min}$. The medium was removed, cells were scraped from the culture dish, and protein in all samples was precipitated with trichloracetic acid, filtered, and counted. 
affect the level of tPA in the culture medium (Table III). Moreover, thrombin inactivated by hirudin did not affect tPA release. To determine whether the high-affinity active siteindependent thrombin receptors were involved in the increase of . tPA release, thrombin was added to the cultures in the presence of excess amounts of DFP-thrombin (20). DFPthrombin does not clot fibrinogen but binds to this set of thrombin receptors in a fashion identical to that of active thrombin (20). Little increase in the level of TPA was observed when the cells were treated with DFP-thrombin at a concentration equivalent to $50 \mathrm{U} / \mathrm{ml}$ (Table III). This amount of DFP-thrombin however did not interfere with the stimulation of $\mathrm{tPA}$ release by $1 \mathrm{U} / \mathrm{ml}$ of active thrombin.

The 6-h delay that occurs between thrombin addition and enhanced tPA release suggests that the increase depends upon other metabolic events. To determine whether protein synthesis or RNA synthesis is involved in the stimulation of tPA release, cultures were treated with either cycloheximide or actinomycin $D$ at various times after thrombin addition, and the amount of tPA present in the conditioned medium was determined (Table IV). No tPA was detected when cycloheximide was added $4 \mathrm{~h}$ after thrombin treatment. The final tPA concentration, however, was 16 and $30 \%$ of uninhibited thrombin treated cultures when cycloheximide was added 6 and $8 \mathrm{~h}$ post-thrombin, respectively. Treatment with actinomycin D also resulted in low tPA levels when added 3 or $4 \mathrm{~h}$ after thrombin (Table IV). However, little effect was noticed when RNA synthesis was stopped $6 \mathrm{~h}$ after thrombin addition and virtually no effect was detected when actinomycin $D$ was added $8 \mathrm{~h}$ after thrombin.

Whereas the concentration of tPA in culture medium may be accurately measured by radioimmunometric assay, measurement of tPA activity is more difficult. Because of the presence of fibrinolytic inhibitors in the culture medium and the association of tPA with this inhibitor, direct assay of tPA

Table III. Effect of DFP Treated Thrombin on TPA Release from Cultured Human Endothelial Cells

\begin{tabular}{lll}
\hline & tPA & tPA \\
\hline & $(n g / m l)$ & (\% untreated controls) \\
Treatment & & \\
None & 1.31 & 100 \\
Thrombin $(1 \mathrm{U} / \mathrm{ml})$ & 7.1 & 540 \\
DFP-thrombin $\ddagger(1 \mathrm{U} / \mathrm{ml})$ & 0.76 & 58 \\
DFP-thrombin $(50 \mathrm{U} / \mathrm{ml})$ & 1.40 & 107 \\
DFP-thrombin $(50 \mathrm{U} / \mathrm{ml})$ & & \\
$\quad+$ thrombin $(1 \mathrm{U} / \mathrm{ml})$ & 7.8 & 595
\end{tabular}

* Confluent cultures of cells were treated with the specified amount of thrombin or DFP-thrombin for $16 \mathrm{~h}$. Results are the average of duplicate determinations.

₹ DFP-treated thrombin was prepared by incubating thrombin with $10 \mathrm{mM}$ DFP for $2 \mathrm{~h}$ at $37^{\circ} \mathrm{C}$, and dialyzed against PBS.
Table IV. Influence of Cycloheximide and Actinomycin D on the Stimulation of IPA Release from Human Endothelial Cells

\begin{tabular}{llr}
\hline Agent & $\begin{array}{l}\text { Hour after } \\
\text { thrombin addition }\end{array}$ & tPA \\
\hline & & $\%$ \\
Cycloheximide $(5 \mu \mathrm{g} / \mathrm{ml})$ & 4 & 4 \\
& 6 & 16 \\
Actinomycin D $(1 \mu \mathrm{g} / \mathrm{ml})$ & 8 & 31 \\
& 3 & 19 \\
& 4 & 30 \\
& 6 & 89 \\
& 8 & 98
\end{tabular}

Confluent cultures were exposed to $1 \mathrm{U} / \mathrm{ml}$ thrombin and either cycloheximide or actinomycin $\mathrm{D}$ was added at the prescribed time. At $14 \mathrm{~h}$ culture medium was removed and tPA concentration was determined by radioimmunometric assay. Results are presented as a percentage of the tPA concentration in cultures treated with thrombin but not metabolic inhibitors and are the average of two experiments performed in duplicate.

activity is unsuitable. It has been demonstrated, however, that exposure of the tPA-inhibitor complex to $1 \%$ SDS for $30 \mathrm{~min}$ at $37^{\circ} \mathrm{C}$ results in the appearance of fibrinolytic activity (10). When this SDS-induced activation of tPA is used in conjunction with SDS-PAGE (to separate fibrinolytic inhibitors from the tPA) followed by fibrin autography (to visualize tPA activity), changes in the level of tPA activity in endothelial cell culture medium can be measured. To determine the effect of thrombin treatment on tPA activity, dose-response experiments were performed by use of 0.001 to $10 \mathrm{U} / \mathrm{ml}$ thrombin and analysis of the conditioned medium for tPA activity (Fig. 4). In agreement with the changes in antigen levels, increasing concentrations of thrombin produced a dose-dependent increase in IPA activity with what appears to be the maximum amount of activity obtained with $1 \mathrm{U} / \mathrm{ml}$. The increase in tPA activity did not result from direct thrombin activation of the inhibitor bound tPA since conditioned medium removed from untreated cells and treated with $1 \mathrm{U} / \mathrm{ml}$ thrombin for $16 \mathrm{~h}$ did not demonstrate increased tPA activity (data not shown).

\section{Discussion}

The interaction of thrombin with endothelial cells modifies the rate of release of several endothelial cell products involved in hemostasis. For example, thrombin stimulates the synthesis and release of prostacyclin (1), adenine nucleotides (3), and von Willebrand factor (6); decreases the secretion of urokinase activity (4); and activates protein $C(5)$ on the surface of endothelial cells.

The present study demonstrates that thrombin induces an increase in the release of tPA from cultures of primary passage 


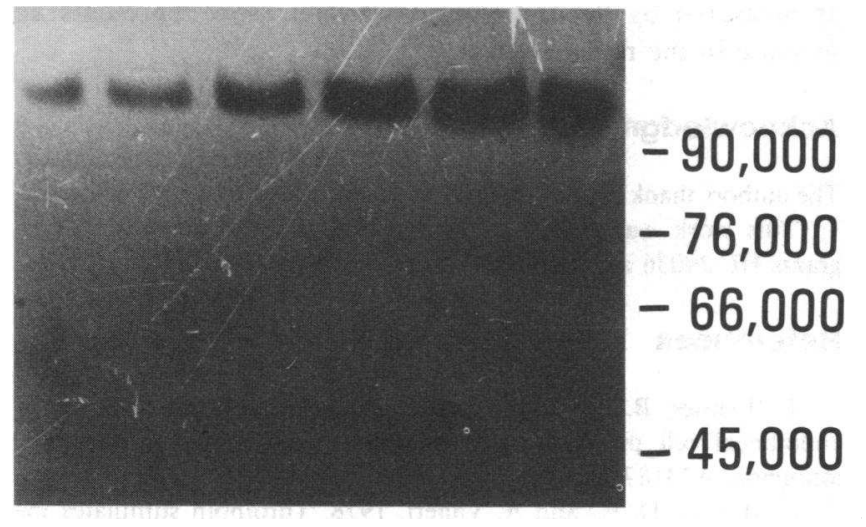

\section{$00.0010 .010 .1 \quad 1 \quad 10$ \\ Thrombin (U/ml)}

Figure 4. Thrombin-mediated increase in TPA activity in conditioned medium. Increasing concentrations of thrombin diluted in serum free RPMI-1640 were added to confluent monolayers of endothelial cells and the cultures were incubated for $16 \mathrm{~h}$. The culture medium was removed, cell debris was removed by centrifugation at $15,000 \mathrm{~g}$, and the IPA activity in $200 \mu \mathrm{l}$ of conditioned medium was determined by fibrin autography as described in Methods.

human endothelial cells. This stimulation is time and dose dependent, saturable, and active site dependent. The response to thrombin is delayed with a significant increase in the rate of release not occurring until $6 \mathrm{~h}$ after thrombin addition. Enhanced release continues for the next $10 \mathrm{~h}$ after which it declines. The thrombin effect does not appear to involve the high affinity, active site-independent thrombin binding sites on the endothelial cells, since prior exposure to excess amounts of DFP-thrombin fail to inhibit increased tPA release. Thus, the mechanism of thrombin-mediated release is similar to that for arachidonate metabolites (21) and von Willebrand factor (6).

Thrombin is intimately involved in the formation of thrombi through its effect on platelets (22) and its role in fibrin formation (23). On the surface it seems inappropriate that this same molecule would enhance the release of a plasminogen activator whose activity could compromise the formation of the fibrin hemostatic plug. However, the delay before enhanced tPA release could allow for the complete formation of the fibrin thrombus before the levels of tPA increased and lysis was subsequently enhanced. This slow response is consistent with an effect on RNA synthesis, protein synthesis, or a response to specific cell cycle events that depend upon the mitogenic properties of thrombin, rather than with a release of an available intracellular tPA pool. Indeed, the cycloheximide and actinomycin $\mathrm{D}$ data indicate that both protein synthesis and RNA synthesis are involved. Cycloheximide addition to thrombin treated cultures results in a reduction of tPA levels in the culture medium. The tPA concentrations in cultures treated at 4,6 , or $8 \mathrm{~h}$ after thrombin $(4,16$, and $30 \%$ of the tPA concentration in uninhibited controls at $14 \mathrm{~h}$ ) approximate the levels at these same times in cultures treated with thrombin alone $(6,16$, and $26 \%$ of the tPA concentration at $14 \mathrm{~h}$, Fig. $3)$, indicating that the tPA detected in cycloheximide treated cultures is released before the cycloheximide addition. In addition, the suppression of RNA synthesis also results in lower tPA levels after thrombin treatment. However, actinomycin $D$ is only effective when added up to $8 \mathrm{~h}$ after thrombin addition (Table IV). Therefore, it appears as if RNA synthesis is necessary for increased release of TPA and the RNA involved is synthesized during the first 6-8 $\mathrm{h}$ after thrombin addition. The calcitonin-stimulated release of plasminogen activators from porcine renal tubular cells (24) and the increase in plasminogen activator production in human fibroblasts by a diffusible factor secreted by malignant murine cells (25) also have been reported to involve protein and RNA synthesis. Thus, the slow response of enhanced tPA release may be a general phenomenon involving RNA and/or protein synthesis, indicating the absence of available intracellular pools of plasminogen activators.

The possibility that protein $\mathrm{C}$ activation may be involved in thrombin induced tPA release should also be considered. Although the endothelial cell cultures are carefully washed before thrombin addition, residual amounts of protein $\mathrm{C}$ may be absorbed onto the cell surface or internalized and then released after media change. Thus, activation of the protein $\mathrm{C}$ by thrombin via thrombomodulin (5) could induce tPA release. Although no direct proof of protein C-stimulated release of tPA from endothelial cells has been presented, in vivo studies (7) suggest that such an intermediate step in the thrombin effect is possible.

If, as is suggested by the data, tPA release is mediated through the slow-binding active site-dependent thrombin receptors (26), the presence of the plasma inhibitors $\alpha_{2}$-macroglobulin and antithrombin III, which rapidly inhibit thrombin, may be important when extrapolating these in vitro results to in vivo mechanisms. Although at present these conflicting observations are difficult to reconcile, recent reports describing the binding of coagulation factors (27) and the activation of prothrombin (28) on the surface of endothelial cells may suggest a mechanism by which thrombin can be generated on and interact with the plasma membrane in such a way as to limit interference by thrombin inhibitors. Whatever the mechanism, it is apparent that the initial 6-h delay and the reduction in tPA release that occurs between 16 and $24 \mathrm{~h}$ does not reflect changes in general cellular metabolism. This is demonstrated by not only the $\left[{ }^{35} \mathrm{~S}\right]$ methionine incorporation studies presented here but also by previous studies of the effect of thrombin on von Willebrand factor release from endothelial cells (6). These 
studies indicated that the enhanced release of von Willebrand factor occurred within $30 \mathrm{~min}$ of thrombin addition and was complete in $\sim 6 \mathrm{~h}$. Thus, thrombin regulation of tPA is independent of another major hemostatic protein.

The addition of thrombin to cultured bovine aortic endothelial cells has previously been shown to produce a rapid decrease in intracellular and secreted plasminogen activator activity (4). The differences in the results recorded for multiple passaged bovine cells and those reported here can be explained by the difference in the types of plasminogen activators produced. Bovine endothelial cells produce multiple forms of plasminogen activator, including both the tissue type and the urokinaselike (8). Studies determining which of these forms was affected by thrombin addition revealed that the urokinase type was eliminated from the culture medium by thrombin treatment whereas the tPA did not appear to be affected (9). Therefore the loss of the urokinase form was apparently responsible for the decline in plasminogen activator activity. Since primary cultures of human endothelial cells do not release urokinase no inhibitory effect was observed. Thus, the response of each of these cell types to thrombin differs substantially. Although the reason for this difference is not known, it may reflect independent regulatory mechanisms for the two endothelial cell-derived plasminogen activators.

The inhibitor-bound tPA that is present in the conditioned medium of cultured human endothelial cells (10) is probably not representative of the vascular tPA that is released from the endothelium. More likely, tPA-inhibitor complex formation follows release from the cells and is promoted in culture by in vitro conditions. This is supported by two observations: $(a)$ The isolation of free tPA from plasma (29) indicates that the tPA released into the vasculature in vivo is free and available for fibrin binding and plasminogen activation. (b) A variety of normal and transformed human cell lines contain free tPA in their culture medium (30). In certain cases both free and inhibitor-bound tPA are observed $(8,30)$, suggesting that the tPA is released in its native state and becomes inhibitor bound in the extracellular environment. On the other hand, conditions favoring complex formation, which are present in cultures of human endothelial cells are: $(a)$ the relatively high concentration of inhibitor in the culture medium, which is estimated to be at least 15 times the level of tPA (unpublished observation); (b) the length of the incubation period, which allows ample time for association to occur; and (c) the static condition of the cell culture system, which allows for maximum local concentration of both inhibitor and tPA with no means of continual clearance and separation of these molecules that might be affected by blood flow. In addition, the spontaneous formation of the bond (10) coupling the tPA to inhibitor and the irreversible nature of the interaction would tend to drive the reaction to completion over the times involved. Thus, although the lack of information about the fate of TPA in vivo makes it difficult to compare in vivo with in vitro events, we conclude that an increase in the level of tPA inhibitor complex as measured by the radioimmunometric assay represents an increase in the release of free tPA.

\section{Acknowledgments}

The authors thank Jennifer Hoock for her excellent technical assistance.

This work was supported by the National Institutes of Health grants HL 29036 and HL 30244.

\section{References}

1. Weksler, B. B., C. W. Ley, E. A. Jaffe. 1978. Stimulation of endothelial cell prostacyclin production by thrombin, trypsin, and ionophore A23187. J. Clin. Invest. 62:923-930.

2. Mosher, D. F., and A. Vaheri. 1978. Thrombin stimulates the production and release of a major surface-associated glycoprotein (fibronectin) in cultures of human fibroblasts. Exp. Cell Res. 112:323334.

3. Pearson, J. D., and J. L. Gordon. 1979. Vascular endothelial and smooth muscle cells in culture selectively release adenine nucleotides. Nature (Lond.). 281:384-386.

4. Loskutoff, D. J. 1979. Effect of thrombin on the fibrinolytic activity of cultured bovine endothelial cells. J. Clin. Invest. 64:329332.

5. Esmon, C. T., and W. G. Owen. 1981. Identification of an endothelial cell co-factor for thrombin catalyzed activation of protein C. Proc. Natl. Acad. Sci. USA. 78:2249-2252.

6. Levine, J. D., J. M. Harlan, L. A. Harker, M. L. Joseph, and R. B. Counts. 1982. Thrombin-mediated release of Factor VIII antigen from human umbilical vein endothelial cells in culture. Blood. 60:531534.

7. Comp, P. C., and C. T. Esmon. 1981. Generation of fibrinolytic activity by infusion of activated protein $\mathrm{C}$ into dogs. J. Clin. Invest. 68:1221-1228.

8. Levin, E. G., and D. J. Loskutoff. 1982. Cultured bovine endothelial cells produce both urokinase and tissue-type plasminogen activators. J. Cell Biol. 94:631-636.

9. Levin, E. G., and D. J. Loskutoff. 1982. Regulation of plasminogen activator production by cultured endothelial cells. Ann. NY Acad. Sci. 401:184-194.

10. Levin, E. G. 1983. Latent tissue plasminogen activator produced by human endothelial cells in culture. Evidence for an enzyme inhibitor complex. Proc. Natl. Acad. Sci. USA. 80:6804-6808.

11. Emeis, J. J., V. W. M. van Hinsbergh, J. H. Verheijen, and G. Wijngaards. 1983. Inhibition of tissue-type plasminogen activator by conditioned medium from cultured human and porcine vascular endothelial cells. Biochem. Biophys. Res. Commun. 110:392-398.

12. Levin, E. G., and D. J. Loskutoff. 1979. Comparative studies of the fibrinolytic activity of cultured vascular cells. Thromb. Res. 15:869-878.

13. Rijken, D. C., F. Juhan-Vague, F. De Cock, and D. Collen. 1983. Measurement of human tissue-type plasminogen activator by a two site immunoradiometric assay. J. Lab. Clin. Med. 101:274-284.

14. Rijken, D. C., and D. Collen. 1981. Purification and characterization of the plasminogen activator secreted by human melanoma cells in culture. J. Biol. Chem. 256:7035-7041.

15. Deutsch, D. G., and E. T. Mertz. 1970. Plasminogen: purification from human plasma by affinity chromatography. Science (Wash. DC). 170:1095-1096. 
16. Thorell, J. I., and B. G. Johansson. 1971. Enzymatic iodination of polypeptides with ${ }^{125}$ I to a high specific activity. Biochim. Biophys. Acta. 251:363-369.

17. Rodbard, D., and J. E. Lewold. 1970. Computer analysis of radioligand assay and radioimmunoassay data. Acta Endocrinol. 64(Suppl. 147):79-103.

18. Weber, K., and M. Osborn. 1969. The reliability of molecular weight determinations by dodecyl sulfate-polyacrylamide gel electrophoresis. J. Biol. Chem. 244:4406-4412.

19. Granelli-Piperno, A., and E. Reich. 1978. A study of protease and protease-inhibitor complexes in biological fluids. J. Exp. Med. 148:223-234.

20. Awbrey, B. J., J. C. Hoak, and W. G. Owen. 1979. Binding of human thrombin to cultured human endothelial cells. J. Biol. Chem. 254:4092-4095.

21. Lollar, P., and W. G. Owen. 1980. Evidence that the effects of thrombin on arachidonate metabolism in cultured human endothelial cells are not mediated by a high affinity receptor. J. Biol. Chem. 255:8031-8034.

22. Packham, M. A., T. F. Mustard, and R. L. Kinlough-Rathbone. 1978. Role of thrombin in platelet function. In Mechanisms of Hemostasis and Thrombosis. C. H. Mielke and R. Rodvien, editors. Symposia Specialists, Miami. 139-166.
23. Murano, G. 1980. A basic outline of blood coagulation. Semin. Thromb. and Hemostasis. 6:140-161.

24. Dayer, J. M., J.-D. Vassalli, J. L. Bobbitt, R. N. Hull, E. Reich, and S. M. Krane. 1981. Calcitonin stimulates plasminogen activator in porcine renal tubular cells: LLC-PK ${ }_{1}$. J. Cell Biol. 91:195-200.

25. Davies, R. L., D. B. Rifkin, R. Tepper, A. Miller, and R. Kucherlapati. 1983. A polypeptide secreted by transformed cells that modulates human plasminogen activator production. Science (Wash. DC). 221:171-173.

26. Lollar, P., J. C. Hoak, and W. G. Owen. 1980. Binding of thrombin to cultured endothelial cells. J. Biol. Chem. 255:1027910283.

27. Stern, D. M., M. Drillings, H. L. Nossel, A. Hurlet-Jensen, P. S. La Gamma, and J. Owen. 1983. Binding of factor IX and IXa to cultured vascular endothelial cells. Proc. Natl. Acad. Sci. USA. 80:4119-4123.

28. Rogers, G. M., and M. A. Shuman. 1983. Prothrombin is activated on vascular endothelial cells by factor $\mathrm{Xa}$ and calcium. Proc. Natl. Acad. Sci. USA. 80:7001-7005.

29. Rijken, D. C., G. Wijngaards, and J. Welberger. 1981. Immunological characterization of plasminogen activator activities in human tissue and body fluids. J. Lab. Clin. Med. 97:477-486.

30. Wilson, E. L., M. L. B. Becker, E. G. Hoal, and E. B. Dowdle. 1980. Molecular species of plasminogen activators secreted by normal and neoplastic cells. Cancer Res. 30:933-938. 